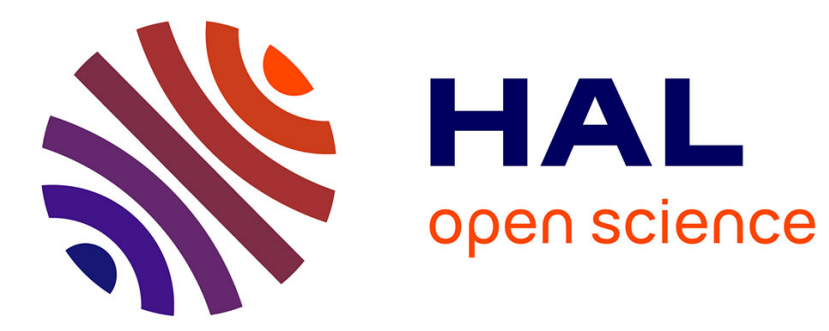

\title{
Iron oxide nanoparticles as heterogeneous electro-Fenton catalysts for the removal of AR18 azo-dye
}

Nouha Ben Hafaiedh, Florence Fourcade, Nizar Bellakhal, Abdeltif Amrane

\section{To cite this version:}

Nouha Ben Hafaiedh, Florence Fourcade, Nizar Bellakhal, Abdeltif Amrane. Iron oxide nanoparticles as heterogeneous electro-Fenton catalysts for the removal of AR18 azo-dye. Environmental Technology, 2020, 41 (16), pp.2146-2153. 10.1080/09593330.2018.1557258 . hal-01976519

HAL Id: hal-01976519

\section{https://hal-univ-rennes1.archives-ouvertes.fr/hal-01976519}

Submitted on 14 Jan 2019

HAL is a multi-disciplinary open access archive for the deposit and dissemination of scientific research documents, whether they are published or not. The documents may come from teaching and research institutions in France or abroad, or from public or private research centers.
L'archive ouverte pluridisciplinaire HAL, est destinée au dépôt et à la diffusion de documents scientifiques de niveau recherche, publiés ou non, émanant des établissements d'enseignement et de recherche français ou étrangers, des laboratoires publics ou privés. 


\section{Iron oxide nanoparticles as heterogeneous electro-Fenton catalysts for the removal of AR18 azo-dye}

Nouha Ben Hafaiedh ${ }^{\mathrm{a}}$, Florence Fourcade ${ }^{\mathrm{b}}$, Nizar Bellakhal ${ }^{\mathrm{a}}$, Abdeltif Amrane $e^{\mathrm{b}, *}$

${ }^{a}$ Institut National des Sciences Appliquees et de Technologie, B.P. No. 676, 1080 Tunis Cedex, Tunisia City, Country

${ }^{b}$ Univ Rennes, Ecole Nationale Supérieure de Chimie de Rennes, CNRS, ISCRUMR6226, F-35000 rennes, France

*Corresponding author: Phone: (+33) 22323 81 55; Fax: (+33) 2232381 20; abdeltif.amrane@univ-rennes1.fr 


\title{
Iron oxides nanoparticle as heterogeneous electro-Fenton catalysts for the removal of AR18 azo-dye
}

\begin{abstract}
Heterogeneous electro-Fenton mineralization of Acid Red 18 (AR18) in aqueous solution was studied with magnetite $\mathrm{Fe}_{3} \mathrm{O}_{4}$ (MNPs) and hematite $\mathrm{Fe}_{2} \mathrm{O}_{3}$ (HNPs) nanoparticles as catalysts. High mineralization yields of AR18 were obtained with magnetite, $81 \%$ TOC removal after $180 \mathrm{~min}$ of electrolysis in $40 \mathrm{mg} . \mathrm{L}^{-1}$ $\mathrm{Fe}_{3} \mathrm{O}_{4}$, pH 3.0, at $50 \mathrm{~mA}$ of current intensity and in $50 \mathrm{mM} \mathrm{Na}_{2} \mathrm{SO}_{4}$. In order to explain the obtained mineralization yield achieved with MNPs, the quantification of hydrogen peroxide $\left(\mathrm{H}_{2} \mathrm{O}_{2}\right)$, hydroxyl radical $(\cdot \mathrm{OH})$ and iron leaching were performed at 50 and $100 \mathrm{~mA}$. From the high iron concentration found in the bulk solution and the slight impact of the catalyst mass concentration on TOC removal, the formation of hydroxyl radicals occurs mainly through homogeneous process. In the presence of hydroxyl radical scavenger, degradation remained total after $15 \mathrm{~min}$ showing the involvement of a direct electrochemical oxidation of the dye at the electrode surface. The hydroxyl radical oxidation is responsible for at least $50 \%$ of mineralization.
\end{abstract}

Keywords: Iron oxides nanoparticles; Hydroxyl radicals; electro-Fenton, Azo-dye

\section{Introduction:}

Advanced oxidation processes (AOPs) are widely documented, owing to their efficiency for the removal of recalcitrant and bio-refractory organic pollutants. AOPs are based on the in situ generation of mainly free hydroxyl radicals [1-3]. This class of processes includes electro-Fenton, a well-used process thanks to its high performance and relevance for an environmental purpose. Recently, more interest has been given to heterogeneous electro-Fenton [4] using zero-valent iron [5, 6], iron based clays [7, 8], iron containing materials $[9,10]$ and iron oxides minerals [11-14]. Great effort have been undertaken to develop active heterogeneous catalysts, such as the use of iron based solid particles [15-18] or hosting iron compounds on different supports [19, 20, 17, 21]. 
Heterogeneous catalysts can be reused, avoiding catalysts waste and making the process economically feasible. The extended range of $\mathrm{pH}$, from $\mathrm{pH} 3$ to $\mathrm{pH} 7$, is attractive as well. Heterogeneous electro-Fenton is therefore considered as a natural evolution of the homogeneous one [22-24]. Due to their specific structure, magnetic properties and their abundance, iron oxides such as magnetite $\left(\mathrm{Fe}_{3} \mathrm{O}_{4}\right)$, hematite $\left(\mathrm{Fe}_{2} \mathrm{O}_{3}\right)$ and goethite $(\alpha-$ FeOOH) are the most commonly used [25-27].

In the heterogeneous electro-Fenton process, hydroxyl radicals are generated either in solution with dissolved $\mathrm{Fe}^{(\mathrm{II})}$ and $\mathrm{Fe}^{(\mathrm{III})}$ ions from the catalyst or on its surface $[17,28]$. In the latest case, hydrogen peroxide is produced at the cathode then transported by convection to the catalyst surface. Take goethite as an example of heterogeneous Fenton catalyst, two mechanisms can oceur on its surface: radical mechanism [29] and non-radical mechanism [30]. In the case of a surface radical mechanism, the reaction starts by the formation of a precursor surface complex $\left(\mathrm{H}_{2} \mathrm{O}_{2}\right)_{\mathrm{s}}$ on the surface of the catalyst. $\left(\mathrm{H}_{2} \mathrm{O}_{2}\right)_{\mathrm{s}}$ leads then to an electronically excited state ligands through a reversible electron transfer. The unstable formed ligands generate $\mathrm{Fe}^{(\mathrm{II})}$ and $\mathrm{HO}_{2}{ }^{\circ} . \mathrm{Fe}^{(\mathrm{II})}$ can then react with either hydrogen peroxide or oxygen to produce • $\mathrm{OH}$ and $\mathrm{HO}_{2}{ }^{\circ}$ respectively. The generated $\mathrm{HO}_{2}{ }^{\circ}$ will decompose and give place to $\mathrm{O}_{2}{ }^{\circ}$. However, the non-radical mechanism is based on the superficial sites of goethite, which are effective for the sorption of the target substrate and $\mathrm{H}_{2} \mathrm{O}_{2}$, reacting on the catalyst surface $[31]$.

Heterogeneous catalysts based on nanoparticles is a promising alternative [32]. It can have properties that are different from those of the bulk forms of the same material. Nanoparticles present improved catalytic activity [33], in comparison with their micro-size counterparts, nano-size particles have few or no mass transfer 
limitations [23], high surface area [34] and are very reactive thanks to their active sites located on the surface which make them easily accessible [27]. A number of studies have shown application of metal nanoparticles as Fenton and electro-Fenton catalysts $[22,35]$. Magnetite nanoparticles catalysts were successfully used to degrade methyl orange azo-dye from aqueous solution in the electro-Fenton process [2]. In another study, the catalytic behaviour of iron (III) oxide-based nanoparticles was investigated for the treatment of contaminated water. Ethylen glycol and phenol were efficiently destroyed by the Fenton-like reaction in the presence of hydrogen peroxide without ultraviolet (UV) light or any radiation source [36]. Moreover, other studies focused on the supported metal nanoparticles, as the degradation of phenol, Rhodamine B and Methyl Blue, which where efficiently degraded using supported $\mathrm{Pd}$ and $\mathrm{Fe}_{3} \mathrm{O}_{4}$ nanoparticles. Sulfamethazine antibiotics was efficiently degraded as well, using synthesized $\mathrm{Fe}_{3} \mathrm{O}_{4}-\mathrm{Mn}_{3} \mathrm{O}_{4}$ nanocomposite [37].

In this study, hematite (HNPs) and magnetite (MNPs) nanoparticles were used to oxidize AR18. As reported in literature by Teja et al. [26], Magnetite has the strongest magnetism of any transition metal oxide, $\mathrm{Fe}^{(\mathrm{III})}$ ions are distributed randomly between octahedral and tetrahedral sites, and $\mathrm{Fe}^{(\mathrm{II})}$ ions are distributed in octahedral sites allowing the Fe species to be reversibly oxidized and reduced while keeping the same structure [23]. The oxygen ions are in cubic close-packed arrangement. However, in hematite, oxygen are in hexagonal close-packed arrangement with $\mathrm{Fe}^{(\mathrm{III})}$ ions occupying octahedral sites. This latest is the oldest known of the iron oxides. HNPs and MNPs have shown high catalytic activity for the oxidation of contaminants $[13,14,2$, $38,39]$.

AR18 dye was chosen as a target compound, since it is extensively employed in food industry, despite its side effects on children behaviour [40]. Treating AR18 azo 
dye is reported in literature by electrochemical methods [40-42]. For Thiam et al. [40] the photo electro-Fenton (PEF) process in the presence of $\mathrm{Fe}^{2+}$ catalyst with low or high oxidation power anodes is the most convenient to ensure quick and total removal of AR18 and its by-products after $360 \mathrm{~min}$. Thiam et al. experimented as well, the mineralization of AR18, they achieved $50 \%$ TOC removal at $150 \mathrm{~mA} \cdot \mathrm{cm}^{-2}$ after $60 \mathrm{~min}$ of electrolysis using PEF with BDD anode and $3 \mathrm{~cm}^{2}$ air-diffusion cathode. The solution was irradiated with $6 \mathrm{~W}$ lamp of $\chi_{\max }=360 \mathrm{~nm}$ [41]. According to previous studies, AR18 discoloration and mineralization were mainly due to the generation of $\bullet$ OH radicals $[41,43]$.

In this work, AR18 mineralization by heterogeneous electro-Fenton process involving hematite and magnetite as nanocatalysts was investigated. The catalysts mass concentrations were examined. Hydrogen peroxide, dissolved iron and hydroxyl radical concentrations were monitored during the mineralization of AR18 using magnetite nanoparticles as catalyst at 50 and $100 \mathrm{~mA}$. The contribution of ${ }^{\bullet} \mathrm{OH}$ radicals on mineralization and discoloration was discussed as well.

\section{Materials and methods}

\section{Chemicals and materials}

AR18 $\left(\mathrm{C}_{20} \mathrm{H}_{11} \mathrm{~N}_{2} \mathrm{Na}_{3} \mathrm{O}_{10} \mathrm{~S}_{3}, 80 \%\right)$ was obtained as powder from a Tunisian food factory and was used without further purification. Magnetite $\left(\mathrm{Fe}_{3} \mathrm{O}_{4}, 97 \%\right)$, hematite $\left(\mathrm{Fe}_{2} \mathrm{O}_{3}\right.$, 98\%) nano-powders and sodium sulfate $\left(\mathrm{Na}_{2} \mathrm{SO}_{4}, 99 \%\right)$ were used as catalyst and supporting electrolyte respectively and were purchased from Sigma Aldrich. DMSO $\left(\mathrm{C}_{2} \mathrm{H}_{6} \mathrm{OS}, 99,7 \%\right)$ and sodium methanesulfonate $\left(\mathrm{CH}_{3} \mathrm{NaO}_{3} \mathrm{~S}, 99 \%\right)$ were purchased form Sigma Aldrich as well. Thiosulfate $\left(\mathrm{Na}_{2} \mathrm{~S}_{2} \mathrm{O}_{3}, 98,5 \%\right)$ and analytical grade of sulfuric acid were used as a titrant for hydrogen peroxide quantification and $\mathrm{pH}$ 
adjustment respectively, both were purchased from Acros Organics. 1,10 phenantroline, used for the colorimetric determination of Fe ions was purchased from Alfa Aesar. All solutions were prepared with ultrapure water and all the other chemicals used for analysis were purchased from Acros and Sigma Aldrich.

\section{Electrochemical apparatus and procedure}

An electrochemical batch mono-compartment cell with $0.25 \mathrm{~L}$ of solution was used to perform all experiments at ambient temperature $\left(20^{\circ} \mathrm{C}\right)$. The cell was equipped with, first a cylindrical $(\mathrm{Pt})$ electrode $\left(31.2 \mathrm{~cm}^{2}\right)$ as an anode located in the center of the electrochemical reactor to have a good potential distribution. The second electrode was a tridimensional carbon felt piece (Carbone Lorraine RVG 4000 Mersen, Paris La Defense, France) as a cathode $(63 \mathrm{~mm} \times 50 \mathrm{~mm} \times 12 \mathrm{~mm}$ corresponding to a geometrical volume of $\left.37.8 \mathrm{~cm}^{3}\right)$.

AR18 initial concentration was $40 \mathrm{mg} \mathrm{L}^{-1}$; all experiments were carried out in duplicate. The solution was continuously mixed by a magnetic stirrer. The oxygen was provided by bubbling compressed air into the solution $\left(0.5 \mathrm{~L} \cdot \mathrm{min}^{-1}\right)$ for $10 \mathrm{~min}$, before and all along the electrolysis. The electric field was supplied by an ammeter power supply (Microsinic system, Microlab MX 20V-2A, villette d Anthon, France).

The ionic strength was maintained constant by the addition of $50 \mathrm{mM} \mathrm{Na}_{2} \mathrm{SO}_{4}$.

\section{Analytical methods}

Total organic carbon (TOC) measurement

The total organic carbon removal of AR18 solution was measured using $\mathrm{TOC}-\mathrm{V}_{\mathrm{cpH} / \mathrm{CPG}}$ total organic analyzer Schimadzu. The amount of $\mathrm{CO}_{2}$ formed, through the catalytic combustion and conversion of organic carbon compounds, was quantified using a nondispersive Infra-Red detector (NDIR). 


\section{Hydrogen peroxide quantification}

The concentration of hydrogen peroxide was determined using iodometric method. $\mathrm{H}_{2} \mathrm{O}_{2}$ oxidizes iodide ions to iodine in acidic conditions and in presence of molybdate catalyst, the iodine formed is titrated with thiosulfate solution incorporating the starch indicator [3].

\section{Dissolved iron concentration [44]}

The concentration of dissolved iron ions (Fe(III)+Fe(II)) was measured by colorimetric determination with 1,10 phenantroline as complexic agent [16]. Its absorbance was measured at $510 \mathrm{~nm}$ by a Shimadzu UV-1280 spectrophometer.

\section{Hydroxyl radical quantification}

The electrochemical cell was the same as described above. It was filled with $50 \mathrm{mM}$ sodium sulfate solution at $\mathrm{pH}$ 3. DMSO $(0.25 \mathrm{M})$ and magnetite $\left(40 \mathrm{mg} . \mathrm{L}^{-1}\right)$ were added to the solution without AR18. Compressed air was bubbled 10 min prior to electrodes polarization in order to saturate the solution with dissolved oxygen.

The expected hydroxyl radicals were quantified during $180 \mathrm{~min}$ of electrolysis at 50 and $100 \mathrm{~mA}$, respectively. Thanks to its high reactivity toward ${ }^{\bullet} \mathrm{OH}$ radicals, DMSO is used as a trapping agent to quantify them. In fact, it is oxidized in the medium leading to methanesulfinic acid. This latest will react with two hydroxyl radicals to form methanesulfonate, which can be quantified. Consequently, its quantification leads indirectly to determine the concentration of ${ }^{\bullet} \mathrm{OH}$ radicals. Methanesulfonate quantification was performed by ion chromatography (DIONEX DX120, ThemoScientific, Sunnyvale, USA) supplied with a conductivity detector. Mobile phase and stationary phase were $\mathrm{KOH}$ and an ion exchange column AS19 (4 x $250 \mathrm{~mm}$ ), respectively. A gradient elution mode was chosen to run the analysis, $10 \mathrm{mM}$ of $\mathrm{KOH}$ 
during the first $10 \mathrm{~min}$; then increased linearly up to $45 \mathrm{mM}$ after $25 \mathrm{~min}$ and this concentration was maintained from 25 to $35 \mathrm{~min}$. The flow rate was set at $1 \mathrm{ml} \cdot \mathrm{min}^{-1}$ [3].

\section{Results and discussion}

\section{Effect of catalysts mass concentrations on AR18 mineralization}

The crucial role of catalysts in the generation of hydroxyl radicals in electro-Fenton process has been reported by many authors $[45,2,12,46]$. Since both homogeneous Fenton reaction and heterogeneous one can occur either in the solution or/and at the catalyst surface, an improvement of the mineralization yield would be expected with an increase of heterogeneous catalyst. Two different commercial nanocatalysts (magnetite and hematite) were evaluated in this study for the mineralization of AR18.

Table 1 shows AR18 mineralization yield achieved after three hours of treatment according to the HNPs mass concentration $\left(40 \mathrm{mg} . \mathrm{L}^{-1}\right.$ or $\left.80 \mathrm{mg} . \mathrm{L}^{-1}\right)$. The increase of the HNPs mass concentration amplified only slightly the mineralization yield, from $72.4 \pm$ 0.4 to $75.8 \pm 0.4 \%$ at $50 \mathrm{~mA}$ and from $81.5 \pm 0.2$ to $83 \pm 1 \%$ at $100 \mathrm{~mA}$. In this range of mass concentration, the influence of the hematite catalyst can be considered as negligible. Similar observation was made in the study of Araujo et al. when they studied the oxidation of Drimarene Red X-6BN by heterogeneous Fenton process using hematite as iron nanocatalyst. The increase of mass concentration of hematite from 1 to 5 g. $\mathrm{L}^{-1}$ slightly improved the reactive dye degradation yield. But for 10 g.L $\mathrm{L}^{-1}$ of hematite, the dye removal significantly increased [13]. These results may indicate that in the case of the present study, the range of mass concentration was too low to observe a significant impact. 
Contrarily to hematite, an increase of magnetite mass concentration [Table 1] from 40 to $80 \mathrm{mg} . \mathrm{L}^{-1}$ decreased its TOC removal from $81 \pm 2$ to $55 \pm 4 \%$ at $50 \mathrm{~mA}$ and from 83 \pm 2 to $79 \% \pm 2$ at $100 \mathrm{~mA}$.

Similar results were observed by Nidheesh et al. [12], and they concluded that the increase in magnetite concentration from 10 to $15 \mathrm{mg} \cdot \mathrm{L}^{-1}$ led to scavenging reactions of excess iron species. Such as the reaction of $\mathrm{Fe}^{(\mathrm{III})}$ with $\mathrm{H}_{2} \mathrm{O}_{2}$ (reaction 1) to produce $\mathrm{HOO}^{\bullet}$ having weaker oxidation capability than ${ }^{\bullet} \mathrm{OH}$ radicals. The competition for the consumption of ${ }^{\bullet} \mathrm{OH}$ radicals by $\mathrm{Fe}^{(\mathrm{II})}$ and $\mathrm{H}_{2} \mathrm{O}_{2}$ leads to inefficient consumption of ${ }^{\bullet} \mathrm{OH}$ as shown in (reactions 2, 3 and 4).

$\equiv \mathrm{Fe}^{(\mathrm{III})}+\mathrm{H}_{2} \mathrm{O}_{2} \rightarrow \equiv \mathrm{Fe}^{(\mathrm{III})} \cdot \mathrm{H}_{2} \mathrm{O}_{2} \rightarrow \equiv \mathrm{Fe}^{(\mathrm{II})}+\mathrm{HOO} \bullet+\mathrm{H}^{+}$

$\mathrm{Fe}^{(\mathrm{II})}+\cdot \mathrm{OH} \rightarrow \mathrm{Fe}^{(\mathrm{III})}+\mathrm{HO}-$

$\cdot \mathrm{OH}+\mathrm{H}_{2} \mathrm{O}_{2} \rightarrow \mathrm{HO}_{2} \bullet+\mathrm{H}_{2} \mathrm{O}$

$2^{\bullet} \mathrm{OH} \rightarrow \mathrm{H}_{2} \mathrm{O}_{2}$

At $40 \mathrm{mg} \cdot \mathrm{L}^{-1}, \mathrm{Fe}^{(\mathrm{II})}$-bearing iron mineral, magnetite, is a more effective catalyst than hematite at 50mA for AR18 mineralization and are in accordance with the study of Expósito et al. [16]. They tested hematite and magnetite as electro-Fenton heterogeneous catalyst for aniline removal. Based on their results, homogeneous Fenton reaction was mainly responsible for the oxidation of aniline and the lowest mineralization yield was obtained for hematite because of the low iron ions leaching from the catalyst. 


\section{Influence of the applied current intensity}

Current intensity is an important parameter considering its direct implication in the process operating cost, the regeneration of ferrous catalyst at the cathode (reaction 1) and the generation of $\mathrm{H}_{2} \mathrm{O}_{2}$ (reaction 5) [47]. An increase in both $\mathrm{Fe}^{(\mathrm{II})}$ and $\mathrm{H}_{2} \mathrm{O}_{2}$ as a result of an increase of the current intensity leads to a higher production of ${ }^{\bullet} \mathrm{OH}$ radicals, inducing a higher mineralization of the dye.

$$
\mathrm{O}_{2}+2 \mathrm{H}^{+}+2 \mathrm{e}-\rightarrow \mathrm{H}_{2} \mathrm{O}_{2}
$$

With HNPs catalyst [table 1], the mineralization yield increased when the current intensity varied from $50 \mathrm{~mA}$ to $100 \mathrm{~mA}$; from $72.4 \pm 0.4$ to $81.5 \pm 0.2 \%$ in the presence of $40 \mathrm{mg} . \mathrm{L}^{-1}$ of catalyst and from $75.8 \pm 0.4$ to $83.3 \pm 0.3 \%$ with $80 \mathrm{mg} . \mathrm{L}^{-1}$ catalyst.

On one hand, kinetic rate of $\mathrm{H}_{2} \mathrm{O}_{2}$ production can be increased with current intensity (reaction 5) and on the other hand the oxidation of water at the anode can lead to a greater production of $\mathrm{O}_{2}$ (Reaction 6) [12].

$$
\mathrm{H}_{2} \mathrm{O} \leftrightarrow 1 / 2 \mathrm{O}_{2}+2 \mathrm{H}^{+}+2 \mathrm{e}^{-}
$$

With MNPs catalyst, mineralization yield at 50 and $100 \mathrm{~mA}$ for $40 \mathrm{mg} . \mathrm{L}^{-1}$ recorded a slight increase from $81 \pm 2$ to $83 \pm 2 \%$. Mineralization yield then decreased to $71 \pm 2 \%$ when current intensity achieved $250 \mathrm{~mA}$. Almost the same trend was observed for 80 mg. $\mathrm{L}^{-1}$, since a maximum was also observed for $100 \mathrm{~mA}$.

From 50 to $100 \mathrm{~mA}$, the evolution of the mineralization yield was in accordance with the slight increase of the amount of $\mathrm{H}_{2} \mathrm{O}_{2}$ generated, from $0.9 \pm 0,06 \mathrm{mM}$ to $1.15 \pm 0,09$ $\mathrm{mM}$ after $120 \mathrm{~min}$ of electrolysis (data not shown). The decrease of mineralization yield at $250 \mathrm{~mA}$ for magnetite can be then explained considering competitive reactions such as the electro reduction of $\mathrm{H}_{2} \mathrm{O}_{2}$ (reaction 7), its dismutation in solution (reaction 8), its anodic oxidation (reaction 9) and the hydrogen production (reaction 10) [3].

$$
\mathrm{H}_{2} \mathrm{O}_{2}+2 \mathrm{H}^{+}+2 \mathrm{e}-\rightarrow 2 \mathrm{H}_{2} \mathrm{O}
$$




$$
\begin{aligned}
2 \mathrm{H}_{2} \mathrm{O}_{2} & \rightarrow \mathrm{O}_{2}+2 \mathrm{H}_{2} \mathrm{O} \\
\mathrm{H}_{2} \mathrm{O}_{2} & \rightarrow \mathrm{O}_{2}+2 \mathrm{e}^{-}+2 \mathrm{H}^{+} \\
2 \mathrm{H}^{+}+2 \mathrm{e}^{-} & \rightarrow \mathrm{H}_{2}
\end{aligned}
$$

The iron dissolution during electrolysis with MNPs was studied and the evolution of soluble Fe ions (ferric + ferrous ions) is represented in figure 1 for two current intensities (50 and $100 \mathrm{~mA}$ ). For the first $30 \mathrm{~min}$ of electrolysis a high $\mathrm{Fe}$ ions dissolution was observed for both current intensities (50 and $100 \mathrm{~mA}$ ); then the concentration of dissolved iron species increased with the reaction time until remaining constant after $120 \mathrm{~min}$. The concentration of iron in solution was higher for $100 \mathrm{~mA}$ than for $50 \mathrm{~mA}$. The influence of current intensity on the dissolution of ferrous ions and their regeneration was also observed previously $[28,38]$. Nideesh et al. [17] also found that the increase of electrode potential favor the leaching of metals from magnetite, affecting consequently the pollutant degradation mechanism from surface reaction to Fenton reaction in solution.

Based on these findings the slight increase in TOC removal from $50 \mathrm{~mA}$ to $100 \mathrm{~mA}$ can be attributed to the enhancement of $\mathrm{H}_{2} \mathrm{O}_{2}$ and dissolved iron species production and a better $\mathrm{Fe}^{(\mathrm{II})}$ generation leading to the production of higher amount of ${ }^{\bullet} \mathrm{OH}$ radicals. According to Nideesh et al. [25], a high catalysts leaching induces the generation of - OH radicals in the bulk solution. In contrast, when insignificant iron leaching is observed, ${ }^{\bullet} \mathrm{OH}$ radicals are generated over the catalyst surface. In the current study, high amount of dissolved iron from magnetite $1.39 \pm 0.05 \mathrm{mM}$ at $100 \mathrm{~mA}$ and $1.20 \pm$ $0.02 \mathrm{mM}$ at $50 \mathrm{~mA}$ in the bulk solution was found (Figure 1). If we consider $2.07 \mathrm{mM}$ as the initial theoretical concentration of iron from the catalyst $\left(40 \mathrm{mg} \cdot \mathrm{L}^{-1}\right.$ of $\mathrm{Fe}_{3} \mathrm{O}_{4}$ in $250 \mathrm{~mL}), 67 \%$ at $100 \mathrm{~mA}$ and $58 \%$ at $50 \mathrm{~mA}$ of total iron were leached in solution after 
180 min indicating that homogeneous Fenton reaction plays a major rule in the mechanism of ${ }^{\bullet} \mathrm{OH}$ radicals generation, which is in agreement with the related literature $[38,48]$. Exposito et al. [16] measured the concentration of total Fe dissolved in the solution; it was $21.2 \mathrm{mg} . \mathrm{L}^{-1}$, after $24 \mathrm{~h}$ of electro-Fenton treatment using $1 \mathrm{~g} / \mathrm{L} \mathrm{Fe}_{3} \mathrm{O}_{4}$ catalyst. They suggested that magnetite behaves as iron ions in the solution; accordingly the homogeneous catalytic reaction is dominant and the heterogeneous catalytic reaction can be considered as negligible in the mineralization of organic compounds. Xu et al. [28] investigated the Fenton-like degradation of 2,4-dichlorophenol using $\mathrm{Fe}_{3} \mathrm{O}_{4}$ magnetic nanoparticles. The concentration of total dissolved iron increased as reaction time increased, which can be attributed to the continuous leaching of iron from $1 \mathrm{~g} / \mathrm{L}$ MNPs, achieving $9.8 \mathrm{mg} . \mathrm{L}^{-1}$ of the iron dissolved into the solution after $180 \mathrm{~min}$. They stipulated that the degradation occurs in two stages, an induction and a degradation stage. Induction period is considered as an activation stage involving the dissolution of iron and the second stage is attributed mainly to the bulk homogeneous Fenton reaction [28].

In this way, the evolution of the $\bullet \mathrm{H}$ radicals concentration was carried out at the two tested current intensities (Figure 2). Results showed a higher hydroxyl radical production rate for $100 \mathrm{~mA}$ in comparison to $50 \mathrm{~mA}$ up to $60 \mathrm{~min}$ of electrolysis $\left(210^{-4}\right.$ $\mathrm{mM} . \mathrm{s}^{-1}$ and $10^{-4} \mathrm{mM} \cdot \mathrm{s}^{-1}$ respectively); these results were in accordance with those obtained for $\mathrm{H}_{2} \mathrm{O}_{2}$ generation and iron ion leaching. Moreover, there were in accordance with the AR18 mineralization yield behavior.

\section{Contribution of $\bullet \mathrm{OH}$}

It is important to elucidate the contribution of hydroxyl radicals to AR18 discoloration and mineralization in electro-Fenton process with magnetite as iron catalyst. To do so the contribution of hydroxyl radicals was investigated by radical scavenging. 
Isopropanol in excess $(1 \mathrm{M})$ was chosen as scavenger due to its high reaction rate constant with ${ }^{\bullet} \mathrm{OH}$ radicals $\left(1.9 \times 10^{9}\right) \mathrm{L} \mathrm{mol}^{-1} \mathrm{~s}^{-1}$ [49]. As presented in figure 3, only $26 \%$ at $50 \mathrm{~mA}$ and $30 \%$ at $100 \mathrm{~mA}$ TOC removal were achieved in the same experimental conditions. However, the discoloration percentage remained unchanged, achieving total discoloration after $15 \mathrm{~min}$ of electrolysis at 50 and $100 \mathrm{~mA}$, with excess isopropanol $(1 \mathrm{M})$ with $40 \mathrm{mg} . \mathrm{L}^{-1} \mathrm{Fe}_{3} \mathrm{O}_{4}$ at $\mathrm{pH} 3$ in $250 \mathrm{~mL} \mathrm{Na} \mathrm{SO}_{4} 0.05 \mathrm{M}$ (data not shown).

Based on these results, it can be concluded that ${ }^{\bullet} \mathrm{OH}$ radicals were responsible for more than $50 \%$ of the TOC removal. The AR18 discoloration through cleavage of its chromophore groups [46] was faster than its mineralization but did not depend on hydroxyl radicals oxidation.

To better understand the degradation mechanism, cyclic voltammetry curves were plotted in AR18 solutions, recorded in oxidation and in reduction at $200 \mathrm{mg} . \mathrm{L}^{-1}$ of AR18 in $0.05 \mathrm{M}$ sodium sulfate solution at $\mathrm{pH} 3.0$ and at $20^{\circ} \mathrm{C}$, using vitreous carbon as working electrode (figure 4). In the presence of AR18 an oxidation peak appeared at $0.4 \mathrm{~V} / \mathrm{ECS}$ which led to the conclusion that apart from mediated $\bullet \mathrm{OH}$, AR18 is electroactive and may undergo direct oxidation as well. This can account for the rapid discoloration. This finding is in agreement with Thiam et al. [40]. Moreover, other reactive oxygen species ROS and adsorption phenomena may contribute to the mineralization of the pollutant. Wang et al. [50] investigated the nature of ROS generated from the decomposition of $\mathrm{H}_{2} \mathrm{O}_{2}$ catalyzed by $\mathrm{Fe}_{3} \mathrm{O}_{4}$ MNPs as peroxidase mimetic. They identified the produced ROS with the electron spin resonance (ESR) measurement by the addition of the spin-trapping DMPO, showing that $\bullet \mathrm{OH}$ and $\mathrm{O}_{2}{ }^{-\bullet}$ $/ \mathrm{HO}_{2}{ }^{\bullet}$ radicals are formed and contribute to the pollutant mineralization. 


\section{Conclusion}

Heterogeneous electro-Fenton mineralization of Acid Red18 in aqueous solution was studied with hematite and magnetite as nanocatalysts. In the range of hematite amounts tested, its impact on the mineralization yield was not significant. The increase of the mass concentration of magnetite affected mineralization due to scavenging reactions. However, the highest TOC removal was achieved for magnetite; $83 \pm 2 \%$ at $100 \mathrm{~mA}$ for $40 \mathrm{mg} . \mathrm{L}^{-1}$ of nanocatalyst. Quantification of hydrogen peroxide and hydroxyl radical highlighted the influence of current intensity on the mineralization yields. High Fe iron leaching $67 \%$ at $100 \mathrm{~mA}$ and $58 \%$ at $50 \mathrm{~mA}$ indicate that homogeneous Fenton reaction plays a major role in the mechanism of hydroxyl radicals generation. AR18 electrochemical behavior and hydroxyl radicals scavenger studies revealed that even though ${ }^{\circ} \mathrm{OH}$ are involved in more than $50 \%$ in AR18 mineralization. Current-potential curve obtained by cyclic $\mathrm{c}=$ voltammetry showed the AR18 oxidation at the electrode surface. In this way, AR18 discoloration from the cleavage of the chromophore group can be due to its direct oxidation on the platinum anode.

\section{References}

[1] Fontmorin JM, Fourcade F, Geneste F, et al. Direct electrochemical oxidation of a pesticide 2,4-dichlorophenoxyacetic acid, at the surface of a graphite felt electrode: Biodegradability improvement. Comptes Rendus Chimie. 2014;18:32-38.

[2] Jiang H, Sun Y, Feng J et al. Heterogeneous electro-Fenton oxidation of azo dye methyl orange catalyzed by magnetic $\mathrm{Fe} 3 \mathrm{O} 4$ nanoparticles. Water science and technology. 2016;74:1116-1126. 
[3] Abou Dalle A, Domergue L, Fourcade F, et al. Efficiency of DMSO as hydroxyl radical probe in an Electrochemical Advanced Oxidation Process - Reactive oxygen species monitoring and impact of the current density. Electrochimica Acta. $2017 ; 246: 1-8$

[4] Poza-Nogueiras V, Rosales E, Pazoz M, Sanroman M A. Current advances and trends in electro-Fenton process using heterogeneous catalysts-A review. Chemosphere. 2018;201:399-416.

[5] Stieber M, Putschew A, Jekel M. Treatment of Pharmaceuticals and Diagnostic Agents Using Zero-Valent Iron - Kinetic Studies and Assessment of Transformation Products Assay. Environ. Sci. Technol. 2011; 11:4944-4950.

[6] Xu L, Wang J. A heterogeneous Fenton-like system with nanoparticulate zerovalent iron for removal of 4-chloro-3-methyl phenol. Journal of Hazardous Materials. 2011;186:256-264.

[7] Papic S, Koprivanac N, Lonearic BA, et al. Advanced Oxidation Processes in Azo Dye Wastewater Treatment. Water Environment Research. 2006; 78: 572-579.

[8] Navalon S, Alvaro M, Garcia H. Heterogeneous Fenton catalysts based on clays, silicas and zeolites. Applied Catalysis B: Environmental. 2010;99:1-26.

[9] Deng J, Jiang J, Zhang Y, et al. $\mathrm{FeVO}_{4}$ as a highly active heterogeneous Fentonlike catalyst towards the degradation of Orange II. Applied Catalysis B: Environmental. 2008; 84:468-473.

[10] Luo W, Zhu L, Wang N, et al. Efficient Removal of Organic Pollutants with Magnetic Nanoscaled $\mathrm{BiFeO}_{3}$ as a Reusable Heterogeneous Fenton-Like Catalyst. Environ. Sci. Technol. 2010; 44:1786-1791.

[11] Lin ZR, Zhao L, Dong YH. Quantitative characterization of hydroxyl radical 
generation in a goethite-catalyzed Fenton-like reaction. Chemosphere. 2015;141:712.

[12] Nidheesh PV, Gandhimathi R, Velmathi S, et al. Magnetite as a heterogeneous electro Fenton catalyst for the removal of Rhodamine B from aqueous solution. RSC Advances.2014; 4:5698-5708.

[13] Araujo FVF, Yokoyama L, Teixeira LAC, et al. Heterogeneous Fenton process using the mineral hematite for the discolouration of a reactive dye solution. Brazilian Journal of Chemical Engineering.2011;28(4):605-616.

[14] Fang GD, Zhou DM, Dionysiou DD. Superoxide mediated production of hydroxyl radicals by magnetite nanoparticles: Demonstration in the degradation of 2chlorobiphenyl. Journal of Hazardous Materials. 2013;1:68-75.

[15] Ouiriemmi I, Karrab A, Oturan N, et al. Heterogeneous electro-Fenton using natural pyrite as solid catalyst for oxidative degradation of vanillic acid. 2017; DOI: 10.1016/j.jelechem.2017.05.028

[16] Expósito E, Sánchez-Sánchez CM, Montiel V. Mineral Iron Oxides as Iron Source in Electro-Fenton and Photoelectro-Fenton Mineralization Processes. Journal of the electrochemical society. 2007;8(1154):116-122.

[17] Nidheesh PV. Heterogeneous Fenton catalysts for the abatement of organic pollutants from aqueous solution: a review. RSC Adv. 2015;15:40552-40577.

[18] Andreozzi R, Caprio V, Marotta R. Oxidation of 3,4-dihydroxybenzoic acid by means of hydrogen peroxide in aqueous goethite slurry. Water Research. 2002;36: $2761-2768$.

[19] Ben Hammouda S, Fourcade F, Assadi A, et al. Effective heterogeneous electroFenton process for the degradation of a malodorous compound, indole, using iron 
loaded alginate beads as a areusable catalyst. Applied Catalysis B: Environmental. 2016;1182:47-58.

[20] Poza-Nogueiras V, Arellano M, Rosales E, et al. Heterogeneous electro-Fenton as plausible technology for the degradation of imidazolinium-based ionic liquids. Chemosphere. 2018;1199: 68-75.

[21] Rezgui S, Amrane A, Fourcade F, et al. Electro-Fenton catalyzed with magnetic chitosan beads for the removal of Chlordimeform insecticide. Applied Catalysis B: Environmental. 2018;1226:346-359.

[22] Dhakshinamoorthy A, Navalon S, Alvaro M, et al. Metal Nanoparticles as Heterogeneous Fenton Catalysts. ChemSusChem. 2012;5:46-64.

[23] Rusevova K, Kopinke FD, Georgi A. Nano-sized magnetic iron oxides as catalysts for heterogeneous Fenton-like reactions -Influence of $\mathrm{Fe}(\mathrm{II}) / \mathrm{Fe}(\mathrm{III})$ ratio on catalytic performance. Journal of Hazardous Materials. 2012;242:433-440.

[24] Kwan WP, Voelker BM. Rates of Hydroxyl Radical Generation and Organic Compound Oxidation in Mineral-Catalyzed Fenton-like Systems. Environ. Sci. Technol. 2003;37:1150-1158.

[25] Nidheesh P, Olvera-Vargas H, Oturan N et al. Heterogeneous Electro-Fenton Process: Principles and Applications. Electro-Fenton Process. 2017;61:85-110.

[26] Teja AS, Koh PY. Synthesis, properties, and applications of magnetic iron oxide nanoparticles. Progress in Crystal Growth and Characterization of Materials. $2009 ; 55: 22-45$.

[27] Garrido-Ramírez E, Theng B, Mora M. Clays and oxide minerals as catalysts and nanocatalysts in Fenton-like reactions -A review. Applied Clay Science. 2010; 
47:182-192.

[28] $\mathrm{Xu} \mathrm{L,} \mathrm{Wang} \mathrm{J.} \mathrm{Fenton-like} \mathrm{degradation} \mathrm{of} \mathrm{2,4-dichlorophenol} \mathrm{using} \mathrm{Fe}_{3} \mathrm{O}_{4}$ magnetic nanoparticles. Applied Catalysis B: Environmental. 2012,1123:117-126.

[29] Shu-Sung L, Mirat DG. Catalytic Decomposition of Hydrogen Peroxide on Iron Oxide Kinetics, Mechanism, and Implications. Environmental science \& technology. 1998;32(110):1417-1423.

[30] Roberto A, Vincenzo C, Raffaele M. Oxidation of 3,4-dihydroxybenzoic acid by means of hydrogen peroxide in aqueous goethite slurry. Water Research. 2002; $136: 2761-2768$

[31] Xue X, Hanna K, Deng N. Fenton-like oxidation of Rhodamine B in the presence of two types of iron (II, III) oxide. Journal of Hazardous Materials. 2009;1166:407414.

[32] Shan G, Yan S, Tyagi RD, et al. Applications of Nanomaterials in Environmental Science and Engineering: Review. Practice Periodical of Hazardous, Toxic, and Radioactive Waste Management. 2009;13:110-119.

[33] Perez JM. Iron oxide nanoparticles Hidden talent. Nature Nanotechnology. 2007; $12: 535-536$

[34] Shi F, Tse MK, Pohl MM, et al. Tuning Catalytic Activity between Homogeneous and Heterogeneous Catalysis: Improved Activity and Selectivity of Free Nano$\mathrm{Fe}_{2} \mathrm{O}_{3}$ in Selective Oxidations. Angewandte Chemie. 2007;146:8866-8868.

[35] Tang CN S, Lo I MC. Magnetic nanoparticles: Essential factors for sustainable environmental applications. water research. 2013;47:2613-2632.

[36] Grigory Z, Raphael S. Iron(3) oxide-based nanoparticles as catalysts in advanced organic aqueous oxidation. Water Research. 2008;42:492-498. 
[37] Zhong W, Jianlong W. Degradation of sulfamethazine antibiotics using $\mathrm{Fe}_{3} \mathrm{O}_{4}-$ $\mathrm{Mn}_{3} \mathrm{O}_{4}$ nanocomposite as a Fenton-like catalyst. J Chem Technol Biotechnol. 2017;192:874-883.

[38] Luo M, Yuan S, Tong M, et al. An integrated catalyst of Pd supported on magnetic Fe3O4 nanoparticles: Simultaneous production of $\mathrm{H} 2 \mathrm{O} 2$ and $\mathrm{Fe} 2 \mathrm{D}$ for efficient electro-Fenton degradation of organic contaminants. Water Research. 2014; 48:190-199.

[39] Zhong X, Xiang L, Royer S, et al. Degradation of C.I. Acid Orange 7 by heterogeneous Fenton oxidation in combination with ultrasonic irradiation. Journal of Chemical Technology and Biotechnology. 2011;86.970-977.

[40] Thiam A, Brillas E, Centellas F, et al. Electrochemical reactivity of Ponceau 4R (food additive E124) in different electrolytes and batch cells. Electrochimica Acta. 2015;173:523-533.

[41] Thiam A, Brillas E, Garrido JA, et al. Routes for the electrochemical degradation of the artificial food azo-colour Ponceau 4R by advanced oxidation processes. Applied Catalysis B: Enyironmental.2016;180:227-236.

[42] Malakootian M, Moridi A. Efficiency of electro-Fenton process in removing Acid Red 18 dye from aqueous solutions. Process Safety and Environment Protection. 2017;1111:138-147.

[43] Rahmani AR, Godini K, Nematollahi D, et al. Degradation of azo dye C.I. Acid Red 18 using an eco-friendly and continuous electrochemical process. Korean Journal of Chemical Engineering.2016;33:532-538.

[44] Cadwell D, Adams R. Colorimetric determination of Iron water with Ophenanthroline. Journal of American Water Works Association. 1946;38:727-730. 
[45] Sun SP, Lemley AT. p-Nitrophenol degradation by a heterogeneous Fenton-like reaction on nano-magnetite: Process optimization, kinetics, and degradation pathways. 2011;349:71-79.

[46] Bouzayani B, Meijide J, Pazos M, et al. Removal of polyvinylamine sulfonate anthrapyridone dye by application of heterogeneous electro-Fenton process. Environmental Science and Pollution Research.2017;24:18309-18319.

[47] Da Costa Soares IC, Da Silva DR, Do Nascimento JHO, et al. Functional group influences on the reactive azo dye decolorization performance by electrochemical oxidation and electro-Fenton technologies. Environmental Science and Pollution Research.2017:24:24167-24176.

[48] Matta R, Hanna K, Chiron S. Fenton-like oxidation of 2,4,6-trinitroluene using different iron minerals. Science of the total environment.2007;385:242-251.

[49] Buxton GV, Greenstock CL, Phillip Helman W, et al. Critical Review of Rate Constants for Reactions of Hydrated Electrons, Hydrogen Atoms and Hydroxyl Radicals $(\cdot \mathrm{OH} / \cdot \mathrm{O}-)$ in Aqueous Solution. Journal of Physical and Chemical Reference Data.1988;17(2):513-525.

[50] Wang N, Zhu L, Wang D, et al. Sono-assisted preparation of highly-efficient peroxidase-like $\mathrm{Fe} 3 \mathrm{O} 4$ magnetic nanoparticles for catalytic removal of organic pollutants with H2O2. Ultrasonics Sonochemistry. 2010;117:526-533.

Table 1. Mineralization yield of AR18 as a function of the current intensity with Hematite and Magnetite catalyst after 180 min of electrolysis, at $\mathrm{pH} 3$ in $0.25 \mathrm{~L} \mathrm{Na}_{2} \mathrm{SO}_{4}$ $0.05 \mathrm{M}$. 


\begin{tabular}{|l|c|c|c|c|}
\hline \multirow{2}{*}{} & \multirow{2}{*}{$\begin{array}{c}\text { Catalyst } \\
\text { concentration } \\
\left(\mathrm{mg.L}^{-1}\right)\end{array}$} & \multicolumn{3}{|c|}{ TOC removal (\%) } \\
\cline { 3 - 5 } & 40 & $72.4 \pm 0.4$ & $81.5 \pm 0.2$ & - \\
\hline Hematite & 80 & $75.8 \pm 0.4$ & $83 \pm 1$ & - \\
\cline { 2 - 5 }$\left(\mathrm{Fe}_{2} \mathrm{O}_{3}\right)$ & 40 & $81 \pm 2$ & $83 \pm 2$ & $71 \pm 2$ \\
\hline Magnetite & 80 & $55 \pm 4$ & $79 \pm 2$ & $70 \pm 2$ \\
\cline { 2 - 5 } & $\left(\mathrm{Fe}_{3} \mathrm{O}_{4}\right)$ & & & $\mathrm{I}=100 \mathrm{~mA}$ \\
\hline
\end{tabular}

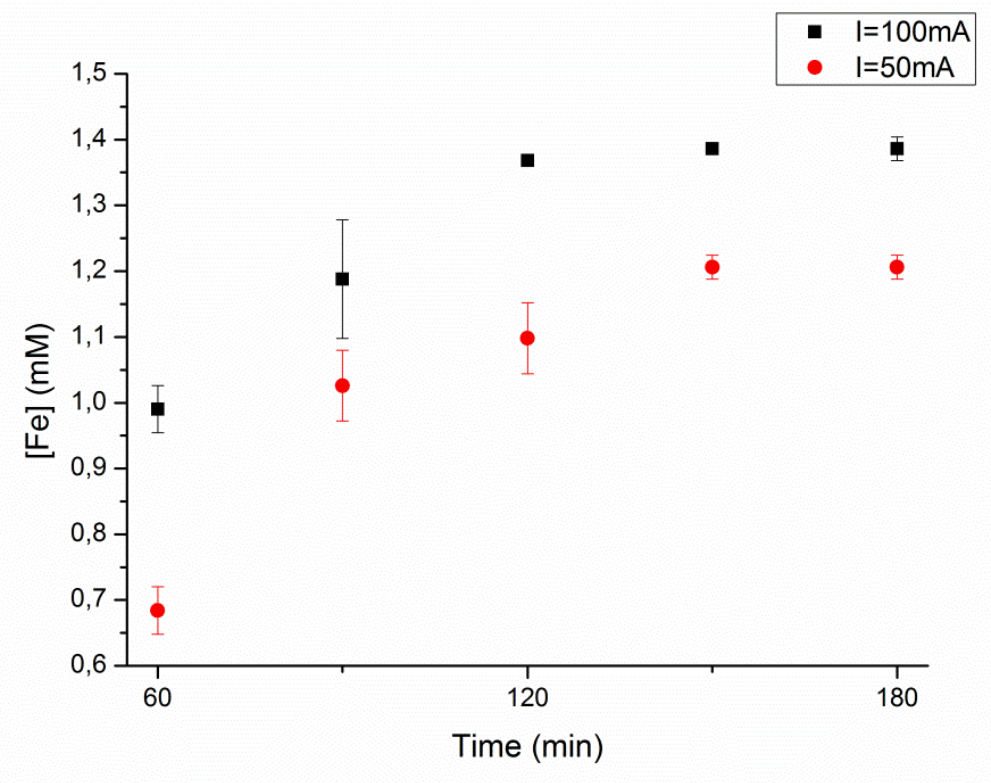

Figure 1. Investigation of $\mathrm{Fe}$ ion dissolution as a function of the current intensity during $180 \mathrm{~min}$, with $40 \mathrm{mg} . \mathrm{L}^{-1} \mathrm{Fe}_{3} \mathrm{O}_{4}$, at $\mathrm{pH} 3$, in $250 \mathrm{~mL} \mathrm{Na}_{2} \mathrm{SO}_{4} 0.05 \mathrm{M}$ 


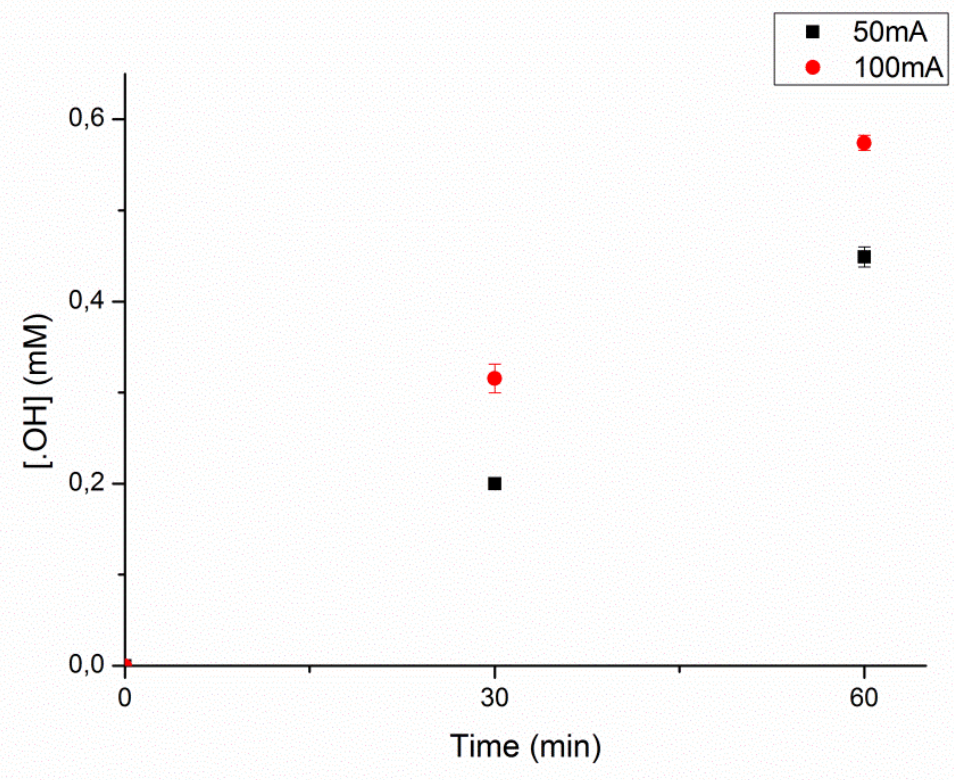

Figure 2. Concentration of generated $\bullet \mathrm{OH}$ as a function of the current density during 180 min of electrolysis, with DMSO $0.25 \mathrm{M}, 40 \mathrm{mg} \cdot \mathrm{L}^{-1} \mathrm{Fe}_{3} \mathrm{O}_{4}$, at $\mathrm{pH} 3$, in $250 \mathrm{~mL}$ $\mathrm{Na}_{2} \mathrm{SO}_{4} 0.05 \mathrm{M}$

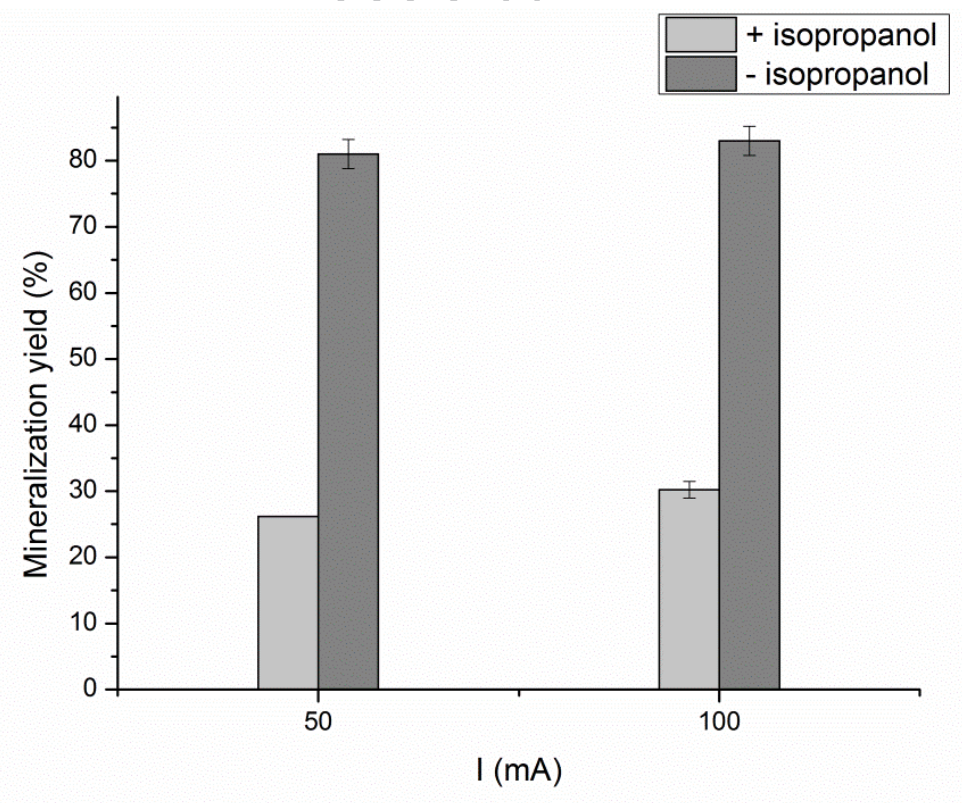


Figure 3 . Mineralization yield of AR18 as a function of the current intensity in presence (light grey bars) and absence (dark grey bars) of isopropanol (1M), with 40 mg. $\mathrm{L}^{-1} \mathrm{Fe}_{3} \mathrm{O}_{4}$, at pH 3, in $250 \mathrm{~mL} \mathrm{Na}_{2} \mathrm{SO}_{4} 0.05 \mathrm{M}$

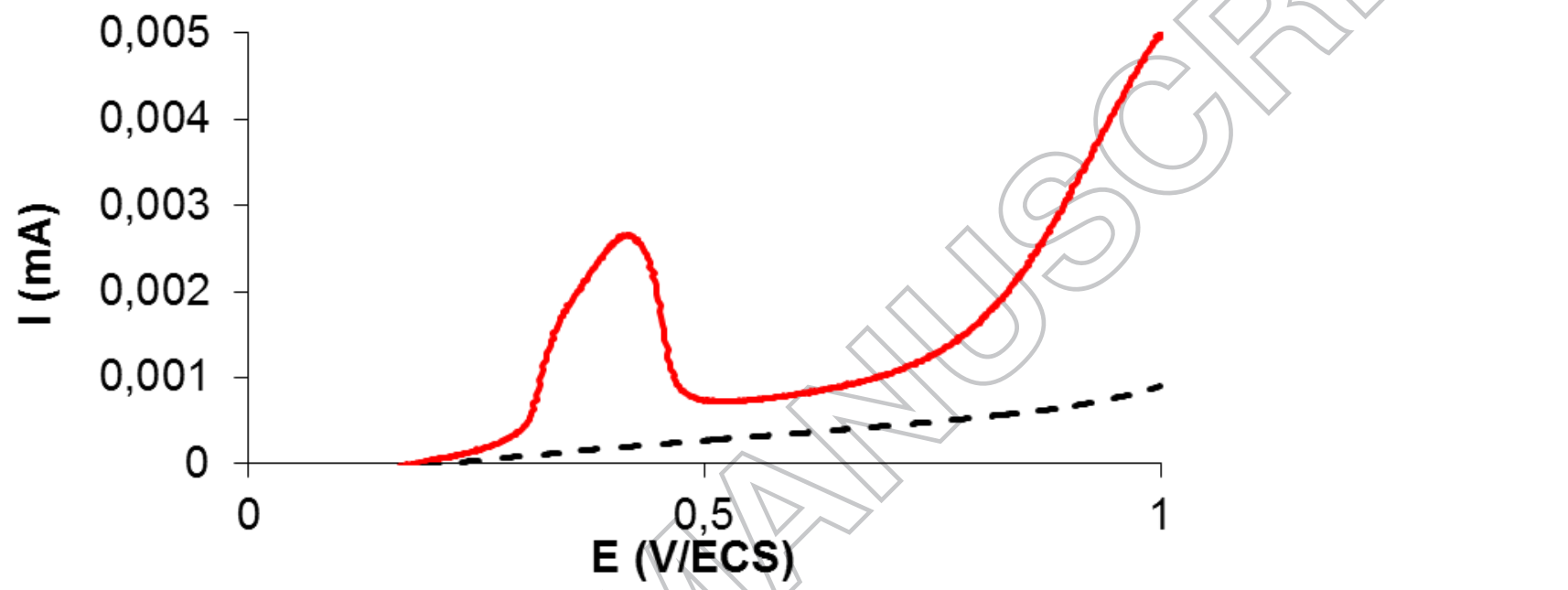

Figure 4. Current-potential curves obtained by cyclic voltammetry with a vitreous carbon electrode $\left(\mathrm{S}=3.14 \mathrm{~mm}^{2}\right)$ as working electrode, a Pt counter electrode and SCE as reference electrode, $\mathrm{r}=50 \mathrm{mV} \mathrm{s}$, under nitrogen atmosphere and room temperature, in $\mathrm{Na}_{2} \mathrm{SO}_{4} 0.05$ mol. $\mathrm{L}^{-1}$ at $\mathrm{pH} 3$ (dotted line) and 200mg.L $\mathrm{L}^{-1}$ AR18 (solid line) 